\title{
PENGEMBANGAN MODUL PEMBELAJARAN BERBASIS GROUP INVESTIGATION DENGAN PENDEKATAN PROBLEM BASED LEARNING PADA MATA KULIAH SISTEM AKUNTANSI MAHASISWA PENDIDIKAN EKONOMI UNIVERSITAS NUSANTARA PGRI KEDIRI
}

\author{
Efa Wahyu Prastyaningtyas ${ }^{1)}$, Hestin Sri Widiawati ${ }^{2)}$ \\ Universitas Nusantara PGRI Kediri \\ efawahyup@gmail.com ${ }^{11}$, hestin.sw@gmail.com ${ }^{2)}$
}

\begin{abstract}
Lecture accounting system is a course that must be taken by students of economic education. Initial observations made by the researcher show that the textbooks owned by the students are still not adequate, so the learning process can not be maximized, especially the teaching materials in the form of print. The research and development of this accounting system module aims to realize the practical learning materials, effective and has relevance to the needs of students. Learning accounting system module developed based on group investigation as research product. The model used in the development of this learning tool is Borg and Gall Model. Broadly speaking step development research consists of three stages: 1) Preliminary study phase, 2) Development study phase 3) Evaluation Phase. The data have been analyzed descriptively quantitatively using inferential statistics using control group and experimental group. The results obtained that the learning-based group investigation module with a problem-based learning approach in the course of effective accounting system is reviewed from the results of understanding the concept and test results of students. This is because the module developed is made interesting with communicative and simple language so that it can be understood by the student.
\end{abstract}

Keywords: Learning Module, Group Investigation, Problem Based Learning, Accounting System

\begin{abstract}
Abstrak
Mata kuliah sistem akuntansi merupakan mata kuliah yang harus ditempuh oleh mahasiswa pendidikan ekonomi. Observasi awal yang dilakukan peneliti menunjukkan buku ajar yang dimiliki mahasiswa masih belum memadai, sehingga proses pembelajaran belum bisa maksimal, khususnya bahan ajar yang berupa cetak. Penelitian dan pengembangan modul sistem akuntansi ini bertujuan untuk mewujudkan bahan pembelajaran praktis, efektif dan memiliki relevansi dengan kebutuhan mahasiswa. Modul pembelajaran sistem akuntansi yang dikembangkan berbasis group investigation sebagai produk penelitian. Model yang digunakan dalam pengembangan perangkat pembelajaran ini adalah Model Borg and Gall. Secara garis besar langkah penelitian pengembangan terdiri dari tiga tahap yaitu: 1) Tahap studi pendahuluan, 2) Tahap studi pengembangan, 3) Tahap Evaluasi.

Data yang sudah dihasilkan dianalisis secara deskriptif kuantitatif menggunakan statistik inferensial dengan menggunakan kelompok kontrol dan kelompok eksperimen. Hasil yang diperoleh bahwa modul pembelajaran berbasis group investigation dengan pendekatan problem based learning mata kuliah sistem akuntansi efektif ditinjau dari hasil pemahaman konsep dan hasil tes mahasiswa. Hal ini disebabkan karena modul yang dikembangkan dibuat secara menarik dengan bahasa komunikatif dan sederhana sehingga dapat dipahami oleh mahasiswa.
\end{abstract}

Kata Kunci: Modul Pembelajaran, Group Investigation, Problem Based Learning, Sistem Akuntansi 


\section{PENDAHULUAN}

Dunia pendidikan menuntut peran serta pendidik (dosen) dalam mengembangkan potensi peserta didik (mahasiswa) agar mampu menghadapi permasalahan kehidupan pada saat terjun ke masyarakat maupun dunia kerja. Dosen harus dapat memahami karakteristik materi dan peserta didik dalam proses pembelajaran terutama berhubungan dengan pemilihan metode pembelajaran yang sesuai dengan materi perkuliahan. Dosen juga dituntut untuk memiliki kompetensi yang tinggi dalam mengembangkan metode pembelajaran, agar dapat menyampaikan materi perkuliahan dengan baik dan dapat menciptakan kondisi belajar yang efektif bagi mahasiswa. Dengan demikian, proses pembelajaran akan lebih bervariasi, inovatif, dan konstruktif sehingga dapat meningkatkan aktivitas dan kemandirian mahasiswa.

Sarana penunjang dalam perkuliahan diperlukan untuk membantu dalam capaian pembelajaran yang efektif. Sarana tersebut antara lain bahan ajar yang berupa modul untuk mata kuliah sistem akuntansi, karena salah satu faktor yang dapat menunjang kemandirian mahasiswa dalam belajar adalah ketersediaan sumber belajar yang memadai. Bahan ajar merupakan sarana atau alat pembelajaran yang berisi materi, metode, batasan-batasan dan cara mengevaluasi pembelajaran yang didesain secara sistematis dan menarik dalam rangka mencapai tujuan yang diharapkan, yaitu mencapai kompetensi dengan segala kompleksitasnya (Lestari, 2013). Pengertian tersebut menggambarkan bahwa bahan ajar seharusnya dibuat dan dirancang sesuai kaidah instruksional, karena nantinya akan digunakan mahasiswa dalam belajar, dan dosen untuk menunjang proses pembelajaran.

Sistem akuntansi merupakan salah satu bidang ilmu yang tidak cukup dipelajari dari sisi teori saja tetapi harus ditunjukkan dalam praktek nyata (Pujiati, 2006). Mempelajari sistem akuntansi secara sistematis dan teratur serta didukung dengan observasi langsung ke lapangan adalah kunci utama untuk menguasai mata kuliah tersebut secara benar. Karena itu agar mahasiswa dapat memahami bagaimana mengimplementasikan sistem akuntansi diperlukan bahan ajar Modul. Buku ini merupakan media belajar yang digunakan untuk membelajarkan secara bersama-sama kemampuan kognitif, psikomotorik dan afektif mahasiswa.

Sistem akuntansi merupakan mata kuliah yang ditempuh oleh mahasiswa Prodi Pendidikan Ekonomi Universitas Nusantara PGRI Kediri. Dimana capaian pembelajaran mata kuliah sistem akuntansi yaitu mahasiswa mampu menganalisis, menyusun dan dapat merancang sistem akuntansi dalam perusahaan jasa, dagang maupun manufaktur secara menyeluruh dan terpadu dengan penekanan pada perancangan dan analisis sistem yang dilakukan secara manual.

Hasil observasi awal menunjukkan bahwa: (1) Buku ajar yang dipakai masih kurang memadai karena buku-buku literatur yang ada di pasar masih banyak terbitan lama, sementara untuk buku-buku terbaru masih sangat terbatas dan jarang, (2) Materi yang ada di buku teks sulit dipahami karena lebih membahas tentang perusahaan manufaktur saja, belum di bahas sistem akuntansi untuk perusahan dagang maupun jasa, (3) Mahasiswa masih kurang dalam memahami buku teks sehingga motivasi untuk belajar mandiri juga berkurang, (4) Perubahan kurikulum Prodi Pendidikan Ekonomi Universitas Nusantara PGRI Kediri berdampak pada perubahan mata kuliah sistem akuntansi dimana kurikulum lama sistem akuntansi terbagi menjadi sistem akuntansi 1 dan sistem akuntansi 2 (6 sks) sementara sekarang hanya menjadi sistem akuntansi saja (4 sks). Keberadaan buku teks belum mampu membangun aktifitas belajar mahasiswa, sehingga berdampak pada rendahnya hasil belajar mahasiswa. 
Hasil belajar mahasiswa dalam mata kuliah sistem akuntansi dapat ditingkatkan dengan cara meningkatkan pemahaman mahasiswa pada materi kuliah tersebut. Persoalannya sekarang adalah bagaimana cara meningkatkan pemahaman mahasiswa pada mata kuliah sistem akuntansi. Dalam upaya meningkatkan motivasi dan hasil belajar mahasiswa maka diperlukan pengembangan bahan ajar yang berupa Modul. Modul yang akan dikembangkan dalam penelitian ini adalah modul yang berbasis group investigation dengan pendekatan problem based learning. Modul ini diharapkan dapat meningkatkan partisipasi, pencapaian akademik dan motivasi mahasiswa.

Berdasarkan uraian masalah di atas, rumusan masalah yang menjadi fokus perbaikan pembelajaran yaitu (1) Bagaimanakah hasil pengembangan modul mata kuliah sistem akuntansi berbasis group investigation dengan pendekatan problem based learning yang valid, praktis dan efektif bagi mahasiswa Pendidikan Ekonomi Universitas Nusantara Kediri?, (2) Bagaimanakah respon mahasiswa Pendidikan Ekonomi terhadap modul yang telah dikembangkan?

\section{METODE PENELITIAN}

Penelitian ini merupakan penelitian pengembangan (Development Research) yang diarahkan untuk mengembangkan bahan ajar bagi mahasiswa. Bahan ajar yang berbasis Group Investigation dengan Pendekatan Problem Based Learning sebagai referensi utama yang dikemas dalam bentuk modul. Populasi pada penelitian ini adalah mahasiswa Pendidikan Ekonomi Universitas Nusantara PGRI Kediri. Sedangkan sampel penelitiannya adalah mahasiswa yang menempuh mata kuliah sistem akuntansi. Prosedur pengembangan modul berbasis group investigation dengan pendekatan problem based learning pada mata kuliah sistem akuntansi menggunakan model Borg dan Gall dengan tahap-tahapannya sebagai berikut:

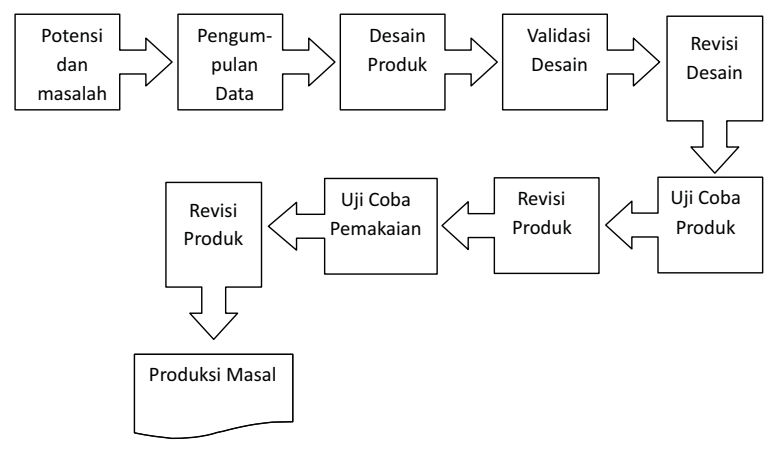

Gambar 1:

Langkah-langkah Penggunaan Metode Research and Development Borg and Gall (Sugiyono, 2010).

Kriteria keberhasilan dari produk pengembangan diukur dengan melakukan pengukuran hasil pembelajaran, yang mencakup tingkat keefektifan, efesiensi, dan daya tarik pembelajaran. Kegiatan ini dilakukan dengan mengadakan pengamatan proses pembelajaran dan tes hasil belajar. Hasil kegiatan ini akan berupa bukti mengenai tingkat keefektifan, efisensi dan daya tarik pembelajaran.

Instrumen pengumpulan data pada penelitaian ini sebagai berikut: (1) Observasi digunakan untuk mendapatkan data tentang kemampuan mengajar dosen, proses kegiatan mahasiswa dan keadaan lingkungan pembelajaran untuk mendapatkan informasi tentang kekurangsesuaiannya dengan strategi pembelajaran yang telah ditetapkan, (2) Wawancara digunakan untuk mendapatkan masukan dari mahasiswa dan teman sejawat tentang proses pembelajaran yang berlangsung, materi perkuliahan dan materi tes yang dilaksanakan. (3) Kuesioner digunakan untuk mendapatkan data dari mahasiswa tentang kualitas proses pembelajaran dan bahan untuk pembelajaran termasuk bahan ajar, pedoman mahasiswa dan tes. (4) Tes digunakan untuk mengetahui efektifitas kegiatan pembelajaran, yaitu berupa tes-awal dan tes-akhir.

Kerangka berpikir dalam penelitian ini disajikan dalam bentuk bagan di bawah ini: 


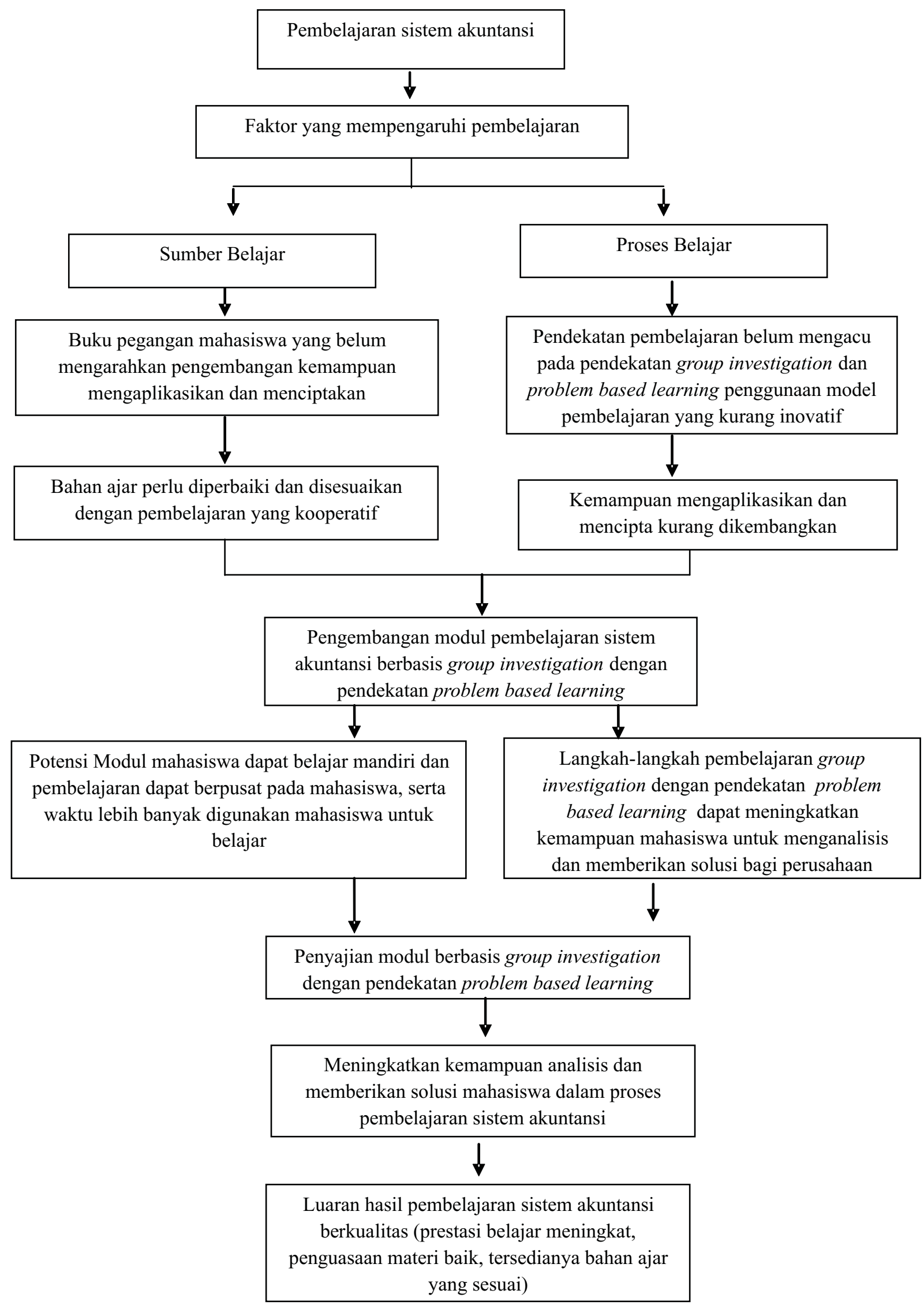

Gambar 2: Kerangka Berpikir Penelitian 


\section{Analisis Data}

Analisis data yang digunakan dalam penelitian ini terdiri dari: 1) analisis deskriptif, yaitu memaparkan hasil penelitian berdasarkan hasil penelitian berdasarkan data yang telah diperoleh untuk mengetahui kelayakan modul yang dikembangkan; 2) analisis kuantitatif dengan menggunakan statistik inferensial.

1). Analisis Deskriptif yang digunakan dalam penelitian ini meliputi tahap analisis kebutuhan, penilaian ahli, uji coba awal dan implementasi. Tahap analisis data yang akan dilakukan adalah sebagai berikut: (1) angket yang telah diisi responden diperiksa kelengkapan jawabannya, kemudian disusun sesuai dengan kode jawabannya, (2) mengkuantifikasi jawaban setiap pertanyaan dengan memberikan skor sesuai dengan bobot yang telah ditentukan, (3) membuat tabulasi data, (4) menghitung persentase dari komponen angket dengan rumus:

$\mathrm{P}=\frac{\sum x i}{\sum x} \times 100 \%$

Keterangan:

$\mathrm{P}=$ prosentase penilaian

$\sum x i=$ jumlah jawaban dari subjek

$\sum x=$ jumlah jawaban tertinggi

Tabel 1. Pengambilan Keputusan Revisi Pengembangan

\begin{tabular}{lll}
\hline Tingkat Pencapaian & Kualifikasi & Keterangan \\
\hline $81 \%-100 \%$ & Sangat baik & Tidak perlu revisi \\
$61 \%-80 \%$ & Baik & Tidak perlu revisi \\
$41 \%-60 \%$ & Cukup & Revisi \\
$21 \%-40 \%$ & Kurang baik & Revisi \\
$0 \%-20 \%$ & Sangat kurang baik & Revisi \\
\hline
\end{tabular}

2) Analisis kuantitatif

Analisis kuantitatif dengan menggunakan statistik inferensial digunakan untuk mengetahui keefektifan modul pembelajaran berbasis group investigation dengan pendekatan problem based learning untuk meningkatkan kemampuan aplikatif dan mencipta mahasiswa. Keefektifan penggunaan modul ini dilihat berdasarkan analisis statistik inferensial dengan uji $t$ menggunakan bantuan analisis SPSS yang didahului dengan uji prasyarat yaitu uji normalitas dan uji homogenitas.

\section{HASIL DAN PEMBAHASAN \\ Deskripsi Modul yang Dikembangkan}

Pengembangan modul pembelajaran dalam penelitian ini menggunakan model Borg \& Gall yang disederhanakan menjadi 3 tahap yaitu tahap studi pedahuluan, tahap studi pengembangan dan tahap evaluasi.
1. Tahap Studi Pendahuluan

Pada tahap ini kegiatan observasi awal dilakukan pada mahasiswa yang menempuh mata kuliah sistem akuntansi. Mata kuliah ini ditempuh oleh mahasiswa tingkat III, pembelajaran sistem akuntansi belum menunjukkan hasil yang optimal. Aktivitas mahasiswa hanya terbatas pada mendengarkan ceramah dosen, diskusi dan tanya jawab. Untuk observasi awal dilakukan pengamatan dan tes. Hasil pengamatan menunjukkan mahasiswa tidak mudah memahami materi sistem akuntansi yang dijelaskan oleh dosen. Mahasiswa masih menganggap bahwa pembelajaran sistem akuntansi merupakan mata kuliah yang sulit, dan mahasiswa kurang aktif dalam proses pembelajaran. Nilai awal mahasiswa pada mata kuliah sistem akuntansi sebelum menggunakan modul: 
Tabel 2. Nilai Awal Mahasiswa

\begin{tabular}{ll}
\hline Nilai & Jumlah \\
\hline A $(91-100)$ & 2 \\
B+(81-90) & 5 \\
B (71-80) & 3 \\
C $(61-70)$ & 15 \\
D (51-60) & 5 \\
E (0-50) & - \\
Jumlah & 30 \\
\hline
\end{tabular}

Hasil observasi awal menunjukkan mahasiswa yang nilainya $\mathrm{B}$ ke atas hanya sebanyak 10 mahasiswa (30\%) dari total 30 mahasiswa yang ada.

Setelah melakukan observasi awal kemudian dilanjutkan dengan mengumpulkan data tentang proses pengajaran (analisis RPP dan SAP) dimana pada tahap ini peneliti mengevaluasi RPP dan SAP yang sudah ada untuk disesuaikan dengan konsep pembelajaran berbasis investigation group dengan pendekatan problem based learning. Langkah selanjutnya penggunaan bahan ajar yaitu melakukan analisis buku-buku teks sistem akuntansi dimana buku yang dipakai dalam proses pembelajaran masih sangat minim dimana buku yang dipakai hanya buku sistem akuntansi karangan Mulyadi dan Zaki Baridwan. Melihat kondisi tersebut maka dibutuhkan pengembangan bahan ajar dengan melakukan analisis literatur yang terkait dengan pengembangan modul dengan tujuan untuk meningkatkan hasil belajar mahasiswa dan memfasilitasi mahasiswa untuk belajar mandiri. Langkah terakhir pada tahap studi pendahuluan yaitu analisis karakteristik mahasiswa serta wawancara dengan teman sejawat dan mahasiswa, tujuannya untuk mengetahui minat dan motivasi mahasiswa terhadap modul yang akan dikembangkan serta memperoleh saran dan masukan baik dari teman sejawat maupun mahasiswa tentang modul tersebut.
2. Tahap Studi Pengembangan

Tahap studi pengembangan dirancang meliputi 5 tahap yaitu:

a. Desain Produk

Pada tahap ini peneliti melakukan perumusan tujuan perkuliahan yaitu mengkonversikan hasil analisis konsep dan analisis tugas menjadi tujuan perkuliahan. Perumusan tujuan perkuliahan didasarkan pada kompetensi dasar dan indikator yang tercantum dalam kurikulum tentang suatu konsep materi.

Langkah dalam mengembangkan draf produk pengembangan modul berbasis group investigation dengan pendekatan problem based learning pada mata kuliah sistem akuntansi adalah sebagai berikut: (1) Pembuatan desain halaman muka (cover), (2) Penulisan bagian pendahuluan, (3) Penulisan bagian inti modul, (4) Penulisan bagian akhir. Dalam tahap desain produk ini, modul yang dikembangkan dengan menggunakan 4 tahapan yaitu menyusun materimateri, latihan-latihan tes tulis maupun praktek sesuai dengan kompetensi, pemilihan media, dan pemilihan metode pembelajaran yang sesuai.

b. Validasi Desain

Pada tahap ini modul yang sudah tersusun hasilnya divalidasi oleh ahli materi, validasi ahli grafis dan validasi praktisi. Validasi ahli dilakukan dengan mengevaluasi modul pembelajaran sistem akuntansi yang dikembangkan yaitu penilaian, saran dan masukan yang dapat dijadikan pedoman untuk merevisi produk awal modul. Validasi yang dilakukan meliputi 2 tahap yaitu tahap 1 dan tahap 2. Berikut ini validasi yang dilakukan oleh ahli materi diperoleh hasil sebagai berikut: 


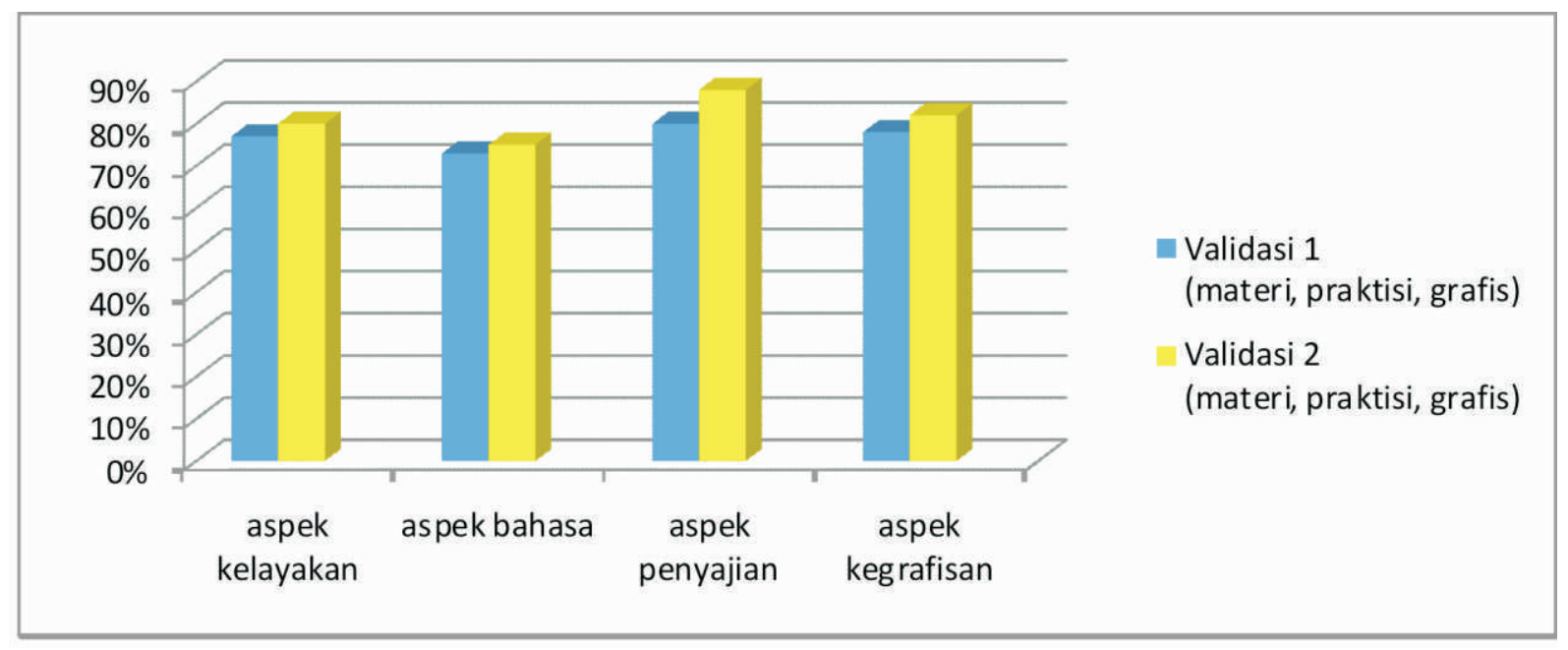

Gambar 3: Diagram hasil validasi ahli materi

Dengan berpedoman pada tabel 1 dan sesuai dengan gambar 1 dapat dijelaskan bahwa hasil validasi ke-1 oleh ahli materi pada aspek kelayakan isi diperoleh rata-rata persentase $77 \%$, aspek bahasa dengan skor $73 \%$, aspek penyajian $80 \%$, dan aspek kegrafisan $78 \%$. Hasil validasi pada tahap 1 menunjukkan bahwa modul yang telah dikembangkan menunjukkan kategori baik tidak perlu revisi baik daria aspek kelayakan, bahasa, penyajian dan kegrafisan. Namun pada tahap validasi ke 1 ini validator menyarankan perlu perbaikan pada tipografi modul, dan sebaiknya menggunakan satu atau dua jenis huruf saja dalam penulisan maupun cover modul. Berdasarkan saran atau masukan para ahli tersebut kemudian modul direvisi. Selanjutnya analisis hasil validasi ke-2 oleh ahli materi pada aspek kelayakan isi diperoleh rata-rata $80 \%$, aspek bahasa mendapat skor $75 \%$, aspek penyajian $88 \%$ dan aspek kegrafisan mendapat skor $82 \%$. Dapat disimpulkan bahwa modul sistem akuntansi yang telah dikembangkan peneliti sudah layak digunakan sebagai salah satu alternatif bahan ajar. c. Revisi Desain

Modul yang telah divalidasi para ahli, kemudian dianalisis untuk diperbaiki kekurangan dan kelemahan modul sistem akuntansi yang akan dikembangkan. Revisi desain yang dilakukan 2 tahap yaitu revisi desain 1 dari hasil validasi ke 1 kemudian diperbaiki sesuai dengan saran validator, dan revisi desain ke 2 tidak ada karena sudah layak.

d. Uji Coba Produk

Uji coba modul pada mahasiswa subjek uji coba. Mahasiswa mempelajari modul yang diberikan, kemudian mahasiswa diminta untuk memberikan pendapatnya berkaitan dengan pengembangan modul.

e. Revisi Produk

Data hasil uji coba produk, kemudian dianalisis untuk mengetahui tanggapan, efektifitas dan kesulitankesulitan yang dialami mahasiswa dalam menggunakan modul.

3. Tahap Evaluasi

Uji coba pemakaian modul menggunakan pre-test dan post test contol design.

Langkah uji coba pemakaian modul berbasis group investigation dengan pendekatan problem based learning meliputi 2 tahap, yaitu: 
a. Uji Coba Terbatas

Uji coba terbatas ini dilakukan untuk melihat keefektifan modul untuk meningkatkan kemampuan hasil belajar mahasiswa. Uji ini dilakukan untuk 30 mahasiswa, dengan menyajikan nilai hasil pre-test dan post-test awal untuk kelas kontrol dan kelas eksperimen. Dilihat dari hasil perhitungan analisis uji wilcoxon dapat dilihat bahwa perolehan hasil uji sebesar -4,786 dan dengan memperhatikan nilai sig yaitu sebesar 0,0001 maka keputusan yang diambil adalah menolak $\mathrm{H}_{0}$ karena nilai sig lebih kecil dari alpha yang telah ditetapkan, yaitu sebesar 0,05. Dengan demikian kesimpulan pengujiannya adalah ada perbedaan nilai post test dengan nilai pre test.
Perbedaan rata-rata antara nilai post-test dan pre-test adalah 15,50. Perbedaan tersebut menunjukkan bahwa nilai post-test lebih baik dari pada nilai pre-test. Dengan demikian dapat disimpulkan bahwa modul berfungsi untuk meningkatkan kemampuan hasil belajar mahasiswa.

b. Uji Coba Lapangan Skala Besar Uji coba ini dilakukan untuk 60 mahasiswa dimana 30 mahasiswa untuk kelas kontrol dan 30 mahasiswa untuk kelas eksperimen.

1) Uji prasyarat analisis data untuk kesamaan dua rata-rata (kemampuan awal)

a. Uji normalitas dan homogenitas data awal sebelum/ sesudah tindakan (Pre-test)

\begin{tabular}{lllll}
\hline Uji Prasyarat & Pre-test kontrol & Sig & $\begin{array}{l}\text { Pre-test } \\
\text { eksperimen }\end{array}$ & Sig \\
\hline Normalitas & 0,861 & 0,448 & 1,177 & 0,125 \\
Homogenitas & 2,379 & 0,065 & 2,501 & 0,061 \\
\hline
\end{tabular}

Dari hasil perhitungan analisis Kolmogorov-Smirnov's Test dapat dilihat hasil uji pre-test pada kelas kontrol sebesar 0,861 dengan nilai sig 0,448 lebih besar dari alpha yang telah ditetapkan yaitu 0,05 . Sedangkan hasil uji pre-test pada kelas eksperimen sebesar 1,177 dengan nilai sig 0,125 lebih besar dari alpha yang ditetapkan yaitu 0,05 maka menunjukkan sampel-sampel yang diambil pada kelompok kontrol maupun kelompok eksperimen berasal dari populasi yang berdistribusi normal. Sedangkan hasil perhitungan analisis Leven's Test dapat dilihat bahwa perolehan hasil uji untuk kelas kontrol sebesar 2,379 dengan nilai sig 0,065 lebih besar dari alpha yang ditetapkan yaitu 0,05 . Sedangkan hasil uji pada kelompok eksperimen 2,501 dengan nilai sig 0,061 lebih besar dari alpha yang ditetapkan yaitu 0,05. Maka sampelsampel yang diambil pada kelompok kontrol dan eksperimen berasal dari populasi yang homogen.

b. Uji hipotesis kesamaan dua rata-rata

Dari hasil perhitungan analisis Levene's Test dapat dilihat bahwa nilai Sig sebesar 0,303 maka keputusan yang diambil adalah menerima $\mathrm{H}_{0}$ karena nilai Sig lebih besar dari alpha yang telah ditetapkan, yaitu 
sebesar 0,05. Dengan demikian hipotesis yang dipakai adalah bahwa kedua varian sama, maka pedoman yang digunakan untuk analisis lanjut adalah nilai pada Equal variances assumed.

Berdasarkan hasil perhitungan analisis Independent-Samples $T$ Test dapat dilihat bahwa nilai Sig pada baris Equal variances assumed yaitu sebesar 0,078 maka keputusan yang diambil adalah menerima $\mathrm{H}_{0}$ karena nilai Sig lebih besar dari alpha yang telah ditetapkan, yaitu sebesar 0,05. Dengan demikian kesimpulan pengujiannya adalah bahwa tidak terdapat perbedaan antara rata-rata nilai kelompok eksperimen dengan rata-rata nilai kelompok kontrol.
Berdasarkan penjelasan di atas maka dapat diambil kesimpulan pengujian secara keseluruhan bahwa sampel-sampel yang diambil mempunyai kemampuan awal yang sama. Hasil analisis data awal yang diperoleh menunjukkan bahwa kelompok eksperimen dan kelompok kontrol merupakan sampel yang berasal dari populasi yang berdistribusi normal. Kedua kelompok tersebut juga berasal dari keadaan awal yang homogen dan mempunyai kemampuan awal yang sama.

2) Uji prasyarat analisis data perbedaan dua rata-rata

a. Uji normalitas dan homogenitas data akhir/setelah tindakan (Post-test)

\begin{tabular}{lllll}
\hline Uji Prasyarat & $\begin{array}{l}\text { Post-test } \\
\text { Kontrol }\end{array}$ & Sig & $\begin{array}{l}\text { Post-test } \\
\text { Eksperimen }\end{array}$ & Sig \\
\hline Normalitas & 1,063 & 0,209 & 0,684 & 0,737 \\
Homogenitas & 2,228 & 0,096 & 1,122 & 0,361 \\
\hline
\end{tabular}

Dari hasil perhitungan analisis Kolmogorov-Smirnov's Test dapat dilihat hasil uji post-test pada kelas kontrol sebesar 1,063 dengan nilai sig 0,209 lebih besar dari alpha yang telah ditetapkan yaitu 0,05 . Sedangkan hasil uji post-test pada kelas eksperimen sebesar 0,684 dengan nilai sig 0,737 lebih besar dari alpha yang ditetapkan yaitu 0,05 maka menunjukkan sampel-sampel yang diambil pada kelompok kontrol maupun kelompok eksperimen berasal dari populasi yang berdistribusi normal dan homogen. Sedangkan hasil perhitungan analisis
Leven's Test dapat dilihat bahwa perolehan hasil uji untuk kelas kontrol sebesar 2,228 dengan nilai sig 0,096 lebih besar dari alpha yang ditetapkan yaitu 0,05 . Sedangkan hasil uji pada kelompok eksperimen 1,122 dengan nilai sig 0,361 lebih besar dari alpha yang ditetapkan yaitu 0,05 . Maka sampel-sampel yang diambil pada kelompok kontrol dan eksperimen berasal dari populasi yang homogen.

b. Uji hipotesis perbedaan dua rata-rata

1) $\mathrm{Hubungan}$ antara kelompok kontrol dan eksperimen 


\begin{tabular}{llcrrr}
\hline \multicolumn{5}{c}{ Paired Samples Correlations } \\
\hline & N & Correlation & Sig. \\
\hline Pair 1 & $\begin{array}{l}\text { Posttest_Eksp \& } \\
\text { Posttest_Kontrol }\end{array}$ & 30 & .285 & .127 \\
\hline
\end{tabular}

Dari tabel Paired Samples

Correlations menunjukkan besarnya korelasi antara kedua kelompok sebesar 0,285 dan nilai Sig sebesar 0,127 maka keputusan yang diambil adalah menerima $\mathrm{H}_{0}$ karena nilai Sig lebih besar dari alpha yang telah ditetapkan, yaitu sebesar 0,05. Dengan demikian menunjukkan bahwa tidak terdapat hubungan yang signifikan antara kelompok eksperimen dengan kelompok kontrol.

2) Pengaruh pembelajaran dengan menggunakan modul berbasis group investigation dengan pendekatan problem based learning.

Paired Samples Test

\begin{tabular}{|c|c|c|c|c|c|c|c|c|c|}
\hline \multicolumn{10}{|c|}{ Paired Differences } \\
\hline & & \multirow[b]{2}{*}{ Mean } & \multirow{2}{*}{$\begin{array}{c}\text { Std. } \\
\text { Devia- } \\
\text { tion }\end{array}$} & \multirow{2}{*}{$\begin{array}{l}\text { Std. } \\
\text { Error } \\
\text { Mean }\end{array}$} & \multicolumn{2}{|c|}{$\begin{array}{l}95 \% \text { Confidence Interval } \\
\text { of the Difference }\end{array}$} & \multirow[b]{2}{*}{$\mathrm{T}$} & \multirow[b]{2}{*}{ df } & \multirow{2}{*}{$\begin{array}{l}\text { Sig. (2- } \\
\text { tailed) }\end{array}$} \\
\hline & & & & & Lower & Upper & & & \\
\hline Pair 1 & $\begin{array}{l}\text { Posttest_Eksp - } \\
\text { Posttest_Kontrol }\end{array}$ & 18.933 & 9.288 & 1.696 & 15.465 & 22.402 & 11.165 & 29 & .000 \\
\hline
\end{tabular}

Dari hasil perhitungan analisis Paired-Samples $T$ Test dapat dilihat bahwa perolehan hasil uji sebesar 11,165 dan perbedaan nilai mean sebesar 18,983 serta dengan memperhatikan nilai Sig yaitu sebesar 0,0001 maka keputusan yang diambil adalah menolak $\mathrm{H}_{0}$ karena nilai Sig lebih kecil dari alpha yang telah ditetapkan, yaitu sebesar 0,05. Dengan demikian kesimpulan pengujiannya adalah bahwa terdapat perbedaan yang signifikan antara rata-rata nilai anak pada kelompok eksperimen dan rata-rata nilai pada kelompok kontrol.

Paired Samples Statistics

\begin{tabular}{llcrrr}
\hline & & & \multicolumn{2}{c}{$\begin{array}{c}\text { Std. } \\
\text { Deviation }\end{array}$} & \multicolumn{2}{c}{$\begin{array}{c}\text { Std. Error } \\
\text { Mean }\end{array}$} \\
\hline Pair 1 & Posttest_Eksp & 85.27 & 30 & 9.074 & 1.657 \\
& Posttest_Kontrol & 66.33 & 30 & 5.845 & 1.067 \\
\hline
\end{tabular}

Dari tabel Paired Samples Statistics dapat dilihat bahwa nilai mean pada kelompok eksperimen sebesar 85,27 dan pada kelompok kontrol sebesar 66,33. Perbedaan nilai mean pada tabel di atas menunjukkan bahwa rata-rata nilai anak pada kelompok eksperimen lebih baik dibandingkan dengan rata-rata nilai anak pada kelompok kontrol.

Dengan demikian dapat disimpulkan bahwa terdapat perbedaan yang signifikan antara rata-rata 
nilai anak pada kelompok eksperimen dan rata-rata nilai anak pada kelompok kontrol mempunyai arti bahwa ada pengaruh yang positif dan signifikan pembelajaran dengan menggunakan modul berbasis group investigation dengan pendekatan problem based learning pada mata kuliah sistem akuntansi.

\section{Respon Mahasiswa terhadap Modul Sistem Akuntansi}

Dari 30 mahasiswa pada kelas eksperimen memberikan tanggapan terhadap 8 pertanyaan menunjukkan pilihan jawaban semua mahasiswa antara sangat setuju dan setuju. Tidak terdapat mahasiswa yang memilih tidak setuju atau sangat tidak setuju. Berdasarkan angket menunjukkan bahwa semua mahasiswa memberi tanggapan positif terhadap penggunaan modul. Pengembangan modul yang telah dihasilkan dalam penelitian ini berbasis group investigation dengan pendekatan problem based learning pada mata kuliah sistem akuntansi berdampak nyata terhadap perbaikan pembelajaran. Potensi modul ini diharapkan mahasiswa dapat belajar mandiri dan pembelajaran berpusat pada mahasiswa, serta waktu lebih banyak digunakan mahasiswa untuk belajar. Dan langkah-langkah pembelajaran yang dipakai dalam pengembangan modul ini dapat meningkatkan kemampuan mahasiswa untuk menganalisis dan memberikan solusi bagi perusahaan.

Pengembangan modul berbasis group investigation dengan pendekatan problem based learning pada mata kuliah sistem akuntansi sebelum di uji cobakan pembelajaran di kelas telah dinyatakan layak karena semua aspek penilaian pada validasi kedua telah mendapatkan kategori baik dan sangat baik.

Tabel 3. Angket Tanggapan Mahasiswa

\begin{tabular}{lccc}
\hline \multicolumn{1}{c}{ Pertanyaan } & \multicolumn{2}{c}{ Pilihan Jawaban } \\
\multicolumn{1}{c}{ Kuliah Sistem Akuntansi memerlukan modul } & 20 & 10 \\
\hline $\begin{array}{l}\text { Mata } \\
\text { pembelajaran }\end{array}$ & & \\
$\begin{array}{l}\text { Pembelajaran dengan modul ini memberikan pengalaman nyata } \\
\text { pada mahasiswa }\end{array}$ & 25 & 5 \\
$\begin{array}{l}\text { Modul ini menyajikan materi yang dipelajari lebih relevan } \\
\text { dengan kenvataan dan kebutuhan }\end{array}$ & 23 & 7 \\
$\begin{array}{l}\text { Mahasiswa memiliki keinginan kuat untuk membaca dan } \\
\text { mempelajari isi modul }\end{array}$ & 25 & 5 \\
$\begin{array}{l}\text { Mata kuliah sistem akuntansi menjadi lebih menarik untuk } \\
\text { dipelajari }\end{array}$ & 18 & 12 \\
$\begin{array}{l}\text { Mahasiswa memiliki kemandirian belajar melalui penggunaan } \\
\text { modul }\end{array}$ & 16 & 14 \\
$\begin{array}{l}\text { Modul berbasis investigation group dan problem based } \\
\text { learning menyajikan kebutuhan mahasiswa pendidikan } \\
\text { ekonomi }\end{array}$ & 26 & 4 \\
Materi sistem akuntansi menarik untuk dipelajari & 22 & 8 \\
\hline
\end{tabular}

Keterangan: SS (sangat setuju), S (setuju) 
Berdasarkan tabel di atas, hasil respon mahasiswa terhadap modul sistem akuntansi menunjukkan secara umum menyatakan modul yang telah dikembangkan sangat dibutuhkan dalam kegiatan perkuliahan karena dapat membantu mahasiswa dalam mempelajari materi dan menarik minat mahasiswa. Output dari hasil pembelajaran sistem akuntansi diharapkan menjadi berkualitas dengan diikuti prestasi belajar meningkat, penguasaan materi baik serta tersedianyan bahan ajar yang sesuai.

\section{Pembahasan}

Hasil penelitian menunjukkan bahwa modul pembelajaran sistem akuntansi yang dikembangkan menunjukkan berkualitas dengan memperhatikan komponenkomponen yang ditetapkan oleh Badan Standar Nasional Pendidikan (BNSP) yaitu komponen aspek kelayakan isi, aspek bahasa dan gambar, aspek penyajian dan kegrafisan. Hasil penilaian terhadap modul sistem akuntansi dikategorikan baik.

Berdasarkan hasil penelitian dan hasil analisis terhadap data perlakuan, diperoleh kesimpulan bahwa modul pembelajaran berbasis group investigation dengan pendekatan problem based learning mata kuliah sistem akuntansi efektif ditinjau dari hasil pemahaman konsep dan hasil tes mahasiswa. Hal ini disebabkan karena modul yang dikembangkan dibuat secara menarik dengan bahasa komunikatif dan sederhana sehingga dapat dipahami oleh mahasiswa. Modul yang dikembangkan dilengkapi dengan soal-soal terbuka yang dapat dikerjakan mahasiswa secara individu maupun mandiri.

Berdasarkan hasil angket respon mahasiswa menunjukkan efektiftas penggunaan modul dilihat dari jawaban mahasiswa, semua menjawab sangat setuju dan setuju dari hasil angket yang telah disebarkan hal tersebut menunjukkan bahwa modul sistem akuntansi yang telah dikembangkan oleh peneliti sudah sangat layak digunakan sebagai alternatif bahan ajar dalam kegiatan perkuliahan sistem akuntansi untuk mahasiswa.

\section{PENUTUP \\ Simpulan}

Pemahaman mahasiswa terhadap materi yang disampaikan dalam perkuliahan dapat meningkatkan hasil belajar mereka. Sebagai upaya untuk meningkatkan motivasi dan hasil belajar mahasiswa maka diperlukan pengembangan bahan ajar yang berupa modul. Modul sistem akuntansi berbasis investigation group dengan pendekatan problem based learning ini diharapkan dapat menjembaatani mahasiswa untuk aktif dalam menyelesaikan permasalahan terutama mahasiswa dapat menganalisis dan memberikan solusi terhadap permasalahan yang menjadi obyek kajian mereka. Untuk mewujudkan itu diperlukan desain modul yang sesuai, dengan mempertimbangkan pengetahuan mahasiswa, serta dosen dapat memberikan petunjuk yang mengarahkan mahasiswa untuk menemukan solusi. Luaran hasil pembelajaran sistem akuntansi dengan menggunakan modul yang telah dikembangkan diharapkan menghasilkan pembelajaran yang berkualitas dengan melihat dari prestasi belajar mahasiswa meningkat, penguasaan materi yang baik, dan tersedianya bahan ajar yang sesuai.

\section{Saran}

Dari hasil penelitian, analisis, pembahasan, simpulan dapat dikemukakan saran sebagai berikut:

1. Pembelajaran menggunakan modul sistem akuntansi berbasis investigation group dengan pendekatan problem based learning dapat dikembangkan oleh dosen secara berkelanjutan untuk mata kuliah yang berbeda.

2. Bagi peneliti selanjutnya kegiatan 
pembelajaran menggunakan modul sistem akuntansi berbasis investigation group dengan pendekatan problem based learning dapat digunakan pada subjek penelitian yang berbeda.

\section{DAFTAR PUSTAKA}

Azhar, Arsyad. 2011. Media Pembelajaran. Jakarta: PT Raja Grafindo Persada.

Alfanika, Amazaki dan Abdurahman. 2014. Pengembangan Model Modul Pembelajaran Bahasa Indonesia Berbasis Investigasi Kelompok (Group Investigation) pada Materi Menulis Krangan Ilmiah siswa Kelas XI SMAN 8 Padang. Jurnal Bahasa, Sastra dan Pembelajaran. 2(2): 47-58

Direktorat Jenderal Pengembangan Mutu Pendidikan dan Tenaga Pendidikan. 2008. Penulisan Modul. Jakarta: Departemen Pendidikan Nasional.

Mulyadi. 2010. Sistem Akuntansi. Yogyakarta: STIE YKPN.

Prastowo. 2011. Panduan kreatif membuat bahan ajar inovatif. Yogyakarta: Diva Press.

Rusman. 2012. Model-model Pembelajaran Mengembangkan Profesionalisme Guru. Jakarta: Raja Grafindo Persada.
Rusmiyati, Arie. 2007. Pengembangan Model Pengajaran dengan Problem Based Instruction pada Pokok Bahasan Fluida untuk Menumbuhkan Keterampilan Proses Sains. FMIPA UNNES.

Slavin, RE. 2010. Cooperative Learning Teori, Riset dan Praktek. Bandung: Nusa Media.

Sumarni. 2012. Model-model Pembelajaran Geografi. Malang: Aditya Media.

Sugiyono. 2010. Metode Penelitian Pendidikan Pendekatan Kuantitatif, KualitatifR\&D. Bandung: Alfabeta.

Saputri, Errlyn Dwi. 2013. Pengembangan Buku Ajar IPA Terpadu Berorientasi CTL. Jurnal Pendidikan sains. 1 (2): 225-228.

Trianto. 2013. Model Pembelajaran Terpadu Dalam Teori Dan Praktek. Jakarta: Prestasi Pustaka.

Warigan. 2007. Strategi Pembelajaran. Jakarta: Penanda Media Group.

Wena. Made. 2012. Strategi Pembelajaran Inovatif Kontemporer. Jakarta: Bumi Aksara.

Zaki, Baridwan. 2012. Sistem Akuntansi (Penyusunan Prosedur \& Metode). Yogyakarta: BPFE. 